\title{
MALAM TUJUH LIKUR PADA MASYARAKAT MELAYU REMPANG CATE KOTA BATAM
}

\section{MALAM TUJUH LIKUR IN THE MALAY COMMUNITY, REMPANG CATE, BATAM CITY.}

\author{
Fitri Yanti ${ }^{1}$, Nina $^{2}$ \\ ${ }^{1,2}$ (Pendidikan Sejarah, Fakultas Keguruan dan Ilmu Pendidikan, Universitas Riau \\ Kepulauan, Indonesia) \\ Fit.ugm@gmail.com
}

\begin{abstract}
Abstrak
Tujuan dari penelitian ini adalah untuk menjelaskan tentang Tradisi Malam Tujuh Likur pada masyarakat Melayu Rempang Cate Kota Batam. Jenis penelitian ini adalah kualitatif dengan menggunakan metode deskriptif. Penelitian ini dilaksanakan di Rempang Cate Kecamatan Galang dengan sumber primer: lurah, ketua adat, tokoh agama, dan masyarakat, sumber sekunder penelitian ini didapatkan melalui dokumentasi. Teknik pengumpulan data dilakukan melalui observasi, wawancara, dan dokumentasi. Hasil penelitian ini menjelaskan pelaksanaan Malam Tujuh Likur dimulai dengan menghantar sesajian dengan membawa berbagai macam kue ke pohon yang dianggap keramat. Sesajian yang dibawa bermakna untuk mencari berkah, atau tidak sakit, dan agar kampung aman dijauhi dari mara bahaya. Selain itu tujuan menghantar sesajian sebagai bentuk penghormatan kepada leluhur. Pelaksanaan yang kedua yaitu memasang pelita, pelita melambangkan jiwa yang terang dan berfungsi sebagai penerangan. Pelaksanaan yang ketiga adalah kenduri. Kenduri bertujuan untuk mendoakan orang yang telah meninggal.
\end{abstract}

Kata kunci: Tradisi, Malam Tujuh Likur, Rempang Cate.

\begin{abstract}
The purpose of this study was to explain Malam Tujuh Likur Tradition in the Malay community of Rempang Cate in Batam City. This type of research is qualitative using descriptive methods. This research was conducted in Rempang Cate, Galang District. The sources of data from the research are two primary sources and secondary sources. The primary sources of this research are village heads, adat leaders, religious leaders, and the community. Secondary sources of this research were obtained through documentation. The technique of collecting data is done through observation, interviews, and documentation. The results of this study explain the implementation of Malam Tujuh Likur begins by delivering offerings by bringing various kinds of cakes to trees that are considered sacred. The offerings were meaningful in seeking blessings, or not getting sick, and so that the village was safely shunned from danger. In addition, the purpose of delivering offerings as a form of respect for ancestors. The second implementation is to install the lamp, the lamp symbolizes a bright soul and functions as illumination. The third implementation is festivity. Kenduri aims to pray for people who have died.
\end{abstract}

Keywords: Tradition, Malam Tujuh Likur, Rempang Cate 


\section{PENDAHULUAN}

Kehidupan suatu masyarakat tidak terlepas dari sebuah kebudayaan, adat istiadat, dan tradisi, yang selalu melekat dalam masyarakat itu sendiri. Pulau Rempang Cate adalah pulau yang terletak di Jembatan Empat Barelang, Kelurahan Rempang Cate Kecamatan Galang. Penduduk asli masyarakat Rempang Cate merupakan masyarakat Melayu, dengan mata pencarian sebagai nelayan.Rempang Cate merupakan pulau yang cukup terpencil sehingga sistem budaya dan tradisinya masih sangat kental belum banyak adanya perubahan. Mayoritas penduduk Rempang Cate masih percaya dengan hal-hal mistik dan makhluk halus ataupun mitos. Meskipun masih berpegang pada ajaran agama Islam.

Masyarakat Melayu Rempang Cate masih memegang tradisi yang bersumber dari nilai-nilai agama Islam, karena agama Islam merupakan agama yang mayoritas di Rempang Cate ini. Hal ini dapat dilihat dari kentalnya nilai Islam dalam budaya masyarakat Melayu Rempang Cate sehingga biasanya perayaan hari besar Islam pun dilakukan secara meriah. Tradisi masyarakat Melayu yang religius menjadi ciri utama adat-istiadat yang terdapat di Rempang Cate. Namun masyarakat Rempang Cate masih percaya terhadap hal mistik dan mitos. Mereka percaya jika tidak melaksanakan petuah dari nenek moyang, mereka akan mendapatkan musibah. Kepercayaan itulah yang membuat Tradisi Malam Tujuh Likur masih dijalankan hingga sekarang.

Setiap Bulan Ramadhan, masyarakat Melayu Rempang Cate menggelar tradisi yang disebut masyarakat setempat Malam Tujuh Likur. Tradisi yang dilakukan sejak masa lalu secara turun-temurun oleh masyarakat Melayu Rempang Cate dengan menyalakan lampu atau penerangan tradisional atau pelita yang ditempatkan diberbagai penjuru jalan, halaman rumah dan teras-teras rumah penduduk. Pada Malam Tujuh Likur anak-anak di Rempang Cate biasanya memainkan kembang api, petasan, dan berjalan membawa obor keliling kampung.

Tradisi Malam Tujuh Likur adalah sebuah bentuk ungkapan syukur masyarakat Melayu Rempang Cate yang telah menjadi tradisi turun temurun. Malam Tujuh Likur biasa diperingati pada malam ke 27 bulan ramadhan. Minggu terakhir di Bulan Ramadhan dipercaya sebagai saat yang istimewa bagi umat Islam, dimana pada minggu terakhir di Bulan Ramadhan, dipercaya sebagai malam Lailatul Qodar yaitu malam diturunkannya Al-Qur'an sebagai kitab suci yang dijadikan petunjuk umat Islam. Hampir seluruh kegiatan yang dilakukan pada Tradisi Malam Tujuh Likur dianggap oleh masyarakat Rempang Cate mengandung arti atau makna-makna tersendiri sehingga makna pada simbol-simbol yang dipecayai oleh masyarakat dianggap dapat menjauhi malapeta dan sebagai bentuk penghormatan kepada leluhur.

\section{Teori Interpretatif Clifford Geertz}

Geertz mendefinisikan kebudayaan merupakan hal yang semiotic dan kontektual, Geertz juga menawarkan cara menafsir simbol-simbol kebudayaan secara komplit (thick). Sebuah tafsiran dengan memaparkan konfigurasi atau sistem simbol-simbol bermakna secara mendalam dan menyeluruh. Mengingat bahwa simbol budaya adalah kendaraan pembawa makna. sistem simbol yang tersedia dalam kehidupan umum masyarakat yang sesungguhnya menunjukkan sistem makna (system of meaning) bagaimana para warga masyarakat yang bersangkutan, 
a. Melihat, merasa, berpikir tentang dunia (sistem gagasan).

b. Bertindak berdasarkan nilai-nilai yang sesuai (sistem tindakan).

c. Akhirnya memanifestasikan diri dalam bentuk-bentuk benda kebudayaan.

Geertz melakukan pendekatan lukisan mendalam, atau (thick description) terhadap kebudayaan. Artinya, pendekatan kebudayaan melalui sebuah penafsiran dengan sistem simbol-simbol bermakna secara mendalam dan menyeluruh. Melalui pendekatan tersebut pembaca mampu dituntun pada teori interpretatif tentang kebudayaan.

\section{Konsep Makna}

Menurut Kridalaksana dalam Lestari (2012:6) makna adalah maksud pembicaraan, pengaruh satuan bahasa dalam pemahaman persepsi atau perilaku manusia atau kelompok manusia, hubungan, dalam arti kesepadanan antara bahasa dan alam di luar bahasa, atau ujaran dan semua hal yang ditujukannya, cara menggunakan lambang-lambang bahasa. Kata makna sebagai istilah, mengacu pada pengertian yang sangat luas. Sebab itu, tidak mengherankan bila Ogden dan Richads dalam bukunya The Meaning of Meaning, mendaftar enam belas rumusan makna yang berbeda-beda antara satu dengan yang lainnya.

\section{Kebudayaan}

Kata "kebudayaan" berasal dari kata sanskerta buddhayah, yaitu bentuk jamak dari buddhi yang berarti "budi" atau "akal". Dengan demikian kebudayaan dapat diartikan: "hal-hal yang bersangkutan dengan akal". Ada sarjana lain yang mengupas kata budaya sebagai suatu perkembangan dari kata majemuk budi-daya, yang berarti" daya dan budi". Karena itu mereka membedakan "budaya" dan "kebudayadan". Demikian " budaya" adalah "daya dan budi" yang berupa cipta, karsa, dan rasa. Sedangkan " kebudayaan" adalah hasil dari cipta, karsa, dan rasa itu (Koeentjaraningrat, 2009: 146). E.B Tylor (1832-1917), budaya adalah suatu keseluruhan kompleks yang meliputi pengetahuan, kpercayaan, kesenian, moral, keilmuan, hukum, adat istiadat, dan kemampuan yang lain, serta kebiasaan yang didapat oleh manusia sebagai anggota masyarakat

\section{Tradisi}

Tradisi adalah kebiasaan sosial yang diturunkan dari suatu generasi ke generasi lainnya melalui proses sosialisasi. Tradisi menentukan nilai-nilai dan moral masyarakat, karena tradisi merupakan aturan-aturan tentang hal apa yang benar dan hal apa yang salah menurut warga masyarakat. Konsep tradisi itu meliputi pandangan dunia (world view) yang menyangkut kepercayaan mengenai masalah kehidupan dan kematian serta peristiwa alam dan makhluknya atau konsep tradisi itu berkaitan dengan sistem kepercayaan, nilai-nilai, dan pola serta cara berfikir masyarakat (Gibran, 2015: 3).

\section{Masyarakat}

Masyarakat adalah suatu kelompok manusia yang telah memiliki tatanan kehidupan, norma-norma, adat-istiadat yang sama-sama ditaati dalam lingkungan nya. Tatanan kehidupan, norma-norma yang mereka miliki itulah yang menjadi dasar 
kehidupan sosial dalam lingkungan mereka, sehingga dapat membentuk suatu kelompok manusia yang memiliki ciri kehidupan yang khas (Noor, 2007: 84).

\section{METODOLOGI}

Jenis penelitian ini adalah penelitian kualitatif dengan menggunakan metode deskriptif. Penelitian kualitatif adalah jenis penelitian yang menekankan pada quality atau hal yang terpenting dari sifat suatu barang atau jasa. Penelitian kualitatif dapat didesain untuk memberikan sumbangannya terhadap teori, praktis, kebijakan, masalah-masalah sosial dan tindakan (Satori \& Komariah, 2011: 28).

Metode yang digunakan dalam penelitian ini adalah metode deskriptif. Metode deskriptif adalah suatu metode dalam meneliti status sekelompok manusia, suatu objek, suatu set kondisi atau suatu sistem pemikiran, ataupun suatu kelas peristiwa pada masa sekarang. Tujuan dari penelitian deskriptif ini adalah untuk membuat deskripsi, faktual dan akurat mengenai fakta-fakta, sifat-sifat, serta hubungan antar fenomena yang diselidiki (Nazir, 2014: 43 ).

Penelitian ini dilakukan di Rempang Cate Kecamatan Galang Kota Batam Provinsi Kepulauan Riau. Waktu pelaksanaan penelitian dilakukan selama 3 bulan dimulai bulan April-Juni 2018. Sumber data yang digunakan dalam penelitian ini yaitu sumber data primer dan sekunder. Sumber primer adalah data yang diperoleh langsung dari subjek penelitian dengan menggunakan alat pengukuran atau alat pengambilan data langsung pada subjek sebagai sumber informasi yang dicari. Sumber primer pada penelitian ini adalah data yang diperoleh secara langsung melalui wawancara dengan lurah atau kepala desa, pemuka adat, dan tokoh masyarakat (Azwar 1999: 91). Sumber Sekunder atau data tangan ke dua adalah data yang diperoleh lewat pihak lain, tidak langsung diperoleh oleh peneliti dari subjek penelitiannya. Data sekunder biasanya berwujud data dokumentasi atau data laporan yang telah tersedia. Penelitian ini yang menjadi sumber sekunder dalam menyusun penelitian ini adalah buku yang ada di perpustakaan Universitan Riau Kepulauan, Perpustakaan Pemerintah Batam (Azwar 1999: 91).

Teknik pengumpulan data yang digunakan meliputi observasi, wawancara, dan dokumentasi. Observasi merupakan aktivitas pencatatan fenomena yang dilakukan secara sistematis. Pengamatan dapat dilakukan secara terlibat (partisipatif) ataupun nonpartisipatif. Wawancara merupakan teknik pengumpulan data yang sering digunakan dalam penelitian kualitatif. Dokumentasi adalah pengumpulan dokumen dan data-data yang di perlukan dalam permasalahan penelitian lalu ditelaah secara intens sehingga dapat mendukung dan menambah kepercayaan dan pembuktian suatu kejadian (Satori \& Komariah, 2011 : 149).

\section{PEMBAHASAN}

Tradisi Malam Tujuh Likur merupakan tradisi yang ditinggalkan oleh nenek moyang terdahulu. Tradisi ini dilakukan untuk memperingati malam Lailatul Qodar. Pelaksanaan tradisi malam tujuh ini biasanya dilaksanakan Masyarakat Melayu Rempang Cate pada tanggal 27 ramadhan setelah melaksanakan sholat tarawih atau pukul 21.00 WIB. sampai tengah malam setelah setiap rumah selesai dibacakan doa. 
Berikut ini hasil wawancara dengan Bapak Guntur selaku tokoh adat di Rempang Cate:

“ Biesak diek kegiatan malam tujuh likur dekat sikeh diikut oleh semuak masyarakat terkecualik betinak. Pada malam tujuh likur keh masyarakat bekumpul dan budek-budek pon ikut berkumpul dan maen-maen. Budekbudek keh jugek kadeng ngekot urang melaksanakan malam tujuh likur semacam kenduri".

Terjemahan :" Biasanya kegiatan malam tujuh likur disini diikuti oleh semua masyarakat terkecuali perempuan, pada malam tujuh likur ini masyarakat berkumpul dan anak-anak pun ikut berkumpul dan bermain. Anak-anak pun ikut ini juga terkadang mengikuti orang melaksanakan malam tujuh likur seperti kenduri.

Dari kutipan di atas dapat disimpulkan bahwa orang yang terlibat dalam pelaksanaan Tradisi Malam Tujuh Likur ini yaitu semua unsur masyarakat baik bapak-bapak, kakek-kakek, orang dewasa atau pemuda bahkan anak-anak pun ikut merayakan malam tujuh likur ini, dengan mengikuti berbagai kegiatan yang digelar. Mereka ikut merayakan dengan permainan kembang api, dan petasan. Tujuannya untuk merayakan, memeriahkan, dan menghidupkan suasana Malam Tujuh Likur supaya terlihat meriah. Tradisi Malam Tujuh Likur dilakukan secara turun temurun oleh masyarakat Rempang Cate. Malam Tujuh Likur di Rempang Cate dilakukan setelah sholat Tarawih. Terlebih dahulu berkumpul di masjid dengan tujuan untuk merapatkan atau berdiskusi mengenai pembagian kelompok. Warga dikelompokkan utk menetukan pada bagian mana mereka akan ditempatkan. Selain itu berkumpulnya masyarakat di masjid dengan tujuan untuk melakukan doa bersama.

Tradisi malam tujuh sampai sekarang masih banyak dilakukan karena didorong oleh kepercayaan yang kuat terhadat tradisi yang sudah berjalan secara turuntemurun, sehingga mereka tidak berani melanggarnya. Walaupun ada sebagian masyarakat Rempang Cate yang sudah tidak begitu berpegang teguh lagi dengan tradisi tetapi mereka tetap melaksanakannya.

Proses atau tahap pelaksanaan malam tujuh likur ini dilakukan atau dimulai sore hari atau sebelum malam tujuh likur yaitu dengan menghantar sesajian, sehabis magrib memasang pelita, dan setelah sholat terawih kenduri. Adapun tahap kegiatan dalam tradisi malam tujuh likur di Rempang Cate adalah:

\section{Mengantar sesajian}

Sesajian sangat erat kaitannya dengan kepercayaan animisme. Kepercayaan animisme adalah suatu keyakinan masyarakat terhadap roh nenek moyang. Masyarakat mempercayai kehadiran nenek moyang didunia ini yang selalu mengawasi kehidupan manusia dan untuk menghormati keberadaan nenek moyang. Maka masyarakat harus memberikan sesaji. Sesaji yang diberikan disesuaikan dengan kultur masyarakat tersebut. Ada yang memberikan sesaji berupa makanan atau yang lainya .

\section{Memasang Pelita}

Pemasangan pelita pada Tradisi Malam Tujuh Likur di Rempang Cate dilakukan setelah magrib. Sehari sebelum Malam Tujuh Likur biasanya masyarakat bergotong 
royong mempersiapkan tempat pemasangan pelita yang terbuat dari kayu disepanjang jalan kemudian membuat pelita yang akan di gunakan dalam tradisi malam tujuh likur.

\section{Kenduri}

Pada pelaksanaan kenduri biasanya masyarakat Rempang Cate membuat makanan Ringan seperti kue basah dan kue-kue kering. Kenduri di Rempang Cate dilaksanakan pada Malam Tujuh Likur setelah solat terawih. Kenduri adalah adat istiadat masyarakat Rempang Cate yang sudah turun temurun sejak zaman dahulu sampai saat ini. Sebelum kenduri dari rumah ke rumah biasanya masyarakat Rempang Cate berkumpul terlebih dahulu di masjid untuk membagikan kelompok dan berdoa bersama di masjid, setelah itu baru pergi kenduri dari rumah kerumah.

\section{KESIMPULAN}

Tradisi Malam Tujuh Likur di Rempang Cate sudah menjadi suatu tradisi yang mendarah daging didalam kehidupan mereka seakan-akan hal ini sudah menjadi kebiasaan bagi mereka. Pelaksanaan Malam Tujuh Likur di Rempang Cate mempunyai makna yang terkandung didalamnya. Pelaksanaan Malam Tujuh Likur pertama mengantar sesajian makna sebagai bentuk penghormatan terhadap leluhur tujuan nya untuk mencari berkah, keselamatan, dan agar kampung aman, tahapan kedua yaitu memasang pelita, pelita mengandung makna melambangkan jiwa yang terang dan dalam pandangan umum tradisi memasang pelita juga untuk penerangan, sedangkan menurut kepercayaan untuk penerangan bagi roh-roh atau orang yang telah meninggal pulang kerumah. Tahap ketiga yaitu kenduri, kenduri adalah upacara memperingati atau mendoakan orang yang telah meninggal kenduri juga sebagai cara mengirimkan doa kepada Allah atas rezeki yang telah diberikan selain itu agar keluarga yang didatangi memperoleh limpahan rezeki.

\section{REFERENSI}

Azwar, S. 1998.Metode Penelitian. Yogyakarta: Pustaka Pelajar.

Greetz, C. 1992. Tafsir Kebudayaan. Yogyakarta: Kanisius.

Gibran, M.K. 2005. "Tradisi Tabuik Di Kota Pariaman”. Jurnal. Universitas Riau. diunduh 18 Februari

Koentjaraningrat. 2009. Ilmu Antropologi. Jakarta: Rineka Cipta.

Nazir, M. 2014. Metode Penelitian. Bogor: Ghalia Indonesia.

Noor, A. 2007. Ilmu Sosial Dasar (ISD). Bandung: Pustaka Setia.

Satori, Djam'an, \& Komariah Aan. 2011. Metodologi Penelitian Kualitatif. Bandung: Alfabeta. 